\title{
Exposure to Mould and Moisture Damage Is a Potential Risk Factor for the Development of Respiratory Diseases Opinion
}

\author{
Jouni Lohi ${ }^{1}$, , Tiina Tuomela ${ }^{2}$, Tamara Tuuminen ${ }^{3}$ \\ ${ }^{1}$ Department of Pathology, Lappland Central Hospital, Rovaniemi, Finland \\ ${ }^{2}$ Pikkujätti, Medical Center for Children and Youth, Vantaa, Finland \\ ${ }^{3}$ Kruununhaka Medical Center, Helsinki, Finland \\ Email address: \\ jouni.j.lohi@gmail.com (J. Lohi), tiina.tuomela@fimnet.fi (T. Tuomela), tuuminen@gmail.com (T. Tuuminen) \\ ${ }^{*}$ Corresponding author
}

\section{To cite this article:}

Jouni Lohi, Tiina Tuomela, Tamara Tuuminen. Exposure to Mould and Moisture Damage is a Potential Risk Factor for the Development of Respiratory Diseases Opinion. International Journal of Immunology. Vol. 8, No. 3, 2020, pp. 38-41. doi: 10.11648/j.iji.20200803.11

Received: July 17, 2020; Accepted: August 3, 2020; Published: August 10, 2020

\begin{abstract}
Adverse health effects due to indoor air moisture damage has been extensively studied already for thirty years. Expose to dampness microbiota (DM) in buildings is a risk factor for newly onset asthma and other respiratory problems. This exposure increases the rate of upper and lower respiratory tract infections because the function of the cilia cells and the integrity of mucosal layer becomes compromised. The breach of the first defense barrier of innate immunity leads to susceptibility to inhaled impurities and pathogens. Dampness and mould-associated asthma may present with several clinical peculiarities. This asthma may be resistant to treatment, the symptoms may exacerbate during periods with increased outdoor air humidity and rainfalls and this asthma may be associated with chronic obstructive pulmonary disease (COPD). It has been generally recognized that persons sensitized to DM should avoid new and repeated exposure to moldy environment. This recommendation is important especially during the current SARS-CoV2 pandemic.
\end{abstract}

Keywords: Mold Damage, Asthma, Respiratory Symptoms, COVID19, SARS-CoV2

\section{Introduction}

Moisture damage is a common problem worldwide. For example, in Finland, moisture damage occurs in at least $25 \%$ of school buildings, and these problems are also known to occur in individual houses, etc. Climate change and heavy rainfalls were linked to increased moisture damage in the buildings. Risky constructions, wetting and poor maintenance of building constructions, risky building materials, mechanical inadequate ventilation, too low air pressure in the buildings and switching off mechanical ventilation during weekends and holidays are known factors that cause hazardous indoor air moisture accumulation that damages the constructions [1].

According to WHO (2009), the exposure to dampness microbiota (DM) and decay products of the damaged building may result in respiratory symptoms. It has become indisputable already since the report of the WHO that the exposure to DM is associated with higher risks for upper and lower respiratory tract infections [2].

\section{Mehtods and Results}

Here, we refer to a few selected literature reviews and meta-analyses (one per year after 2009) supporting the previous knowledge that the exposure to the components of moisture damage indeed causes a plethora of respiratory problems, and aggravation of existing asthma or its exacerbation. Moreover, it increases the incidence of respiratory infections (Table 1).

\section{Findings and Discussion}

On the basis of recent research several peculiarities of moisture-related asthma should be emphasized.

1) DM -associated asthma is more resistant to treatment. Steroid resistance may be associated with the aberrant 
T-cell activation, particularly in the TH2 / TH17 arm of immunity [3].

2) DM -associated asthma is often accompanied by COPD [4].

3) Patients with asthma who are sensitized to DM may experience symptom exacerbation at higher outdoor air humidity, e.g. in late summer and autumn [5].

Now, it is difficult to assess how these asthma peculiarities should be considered in the patients' management protocols. However, is seems appropriate to consider whether patients with mould-related disease might need higher doses of medication in the fall, for example.

In vitro and in vivo studies have shown a variety of inflammatory, cytotoxic, and immunosuppressive responses to spores, secondary metabolites such as mycotoxins, bacterial toxins, volatile organic compounds and decomposition products of construction building materials. Sensitization, histamine release by both IgE-mediated and non-mediated mechanisms, excessive or deprived immune responses, long-term production of inflammatory mediators leading to tissue damage and chronic low-grade inflammation are pathological mechanisms leading to adverse health effects. Exposure to DM can damage mitochondria and trigger autoimmune reactions. In bronchoalveolar lavage (BAL) of individuals exposed to DM who are symptomatic in moisture damaged-buildings, lymphocytosis and changes in CD8 + / CD4+ T-cell ratios have been reported [6]. Decreased CD19+ B lymphocyte counts in the blood have been observed too [7]. Changes in the CD8+ / CD4+ T-cell ratio in the BAL samples of patients with mould-related disease are typical for allergic alveolitis [reviewed 1]. DM activate and simultaneously deprive innate and adaptive immunity. The components of DM may specifically destroy the function of the cilia cells of the epithelium. Thus, the barrier function of mucosal layer of bronchi may be impaired and inhaled impurities may not be removed properly [1, 8]. This dysfunction of the innate immunity paves the way for better pathogen entry.

From the end of 2019 the Globe has faced an unpresidential epidemiological situation, the pandemic of the SARS-CoV2 virus infection. International health authorities have issued recommendations concerning recognition of the risk groups and their protection, the policy had been adopted almost worldwide. For example, the Centers for Disease Control and Prevention warns people with chronic diseases to take special care during the COVID-19 pandemic (https://www.cdc.gov/coronavirus/2019-ncov/need-extraprecautions/people-at-higher-risk.html). The following risk groups have been identified: the elderly, patients with immune suppression, such as medication, cancer, HIV, genetic immunodeficiencies; patients with hepatitis or chronic renal failure requiring dialysis, asthma or other chronic lung diseases.

DM-associated asthma or a pathological pulmonary condition that is not classified as asthma because not all asthma criteria may have been met, are not mentioned as a risk for COVID-19. This is partly because mould-related disease as a separate nosology has not been yet included into the International Classification of Diseases making statistics of this disease inaccurate and less visible. Therefore, due to this hurdle it is difficult to accumulate evidence that the exposure to DM is indeed a risk factor for COVID-19, but we can extrapolate this claim through the existing knowledge.

Table 1. A selection of meta-analyses and literature reviews one/year after 2009 providing additional evidence that residential moisture and mould damage are independent risk factors for adverse respiratory health effects and respiratory infections in particular.

\begin{tabular}{|c|c|c|}
\hline Publication type and the publication year & Study design and main conclusions & Reference \\
\hline Quantitative meta-analysis, 2010 & $\begin{array}{l}\text { Twenty-three original publications were included. } \\
\text { Residential moisture and mould damage are associated with a significant risk for respiratory } \\
\text { infections and bronchitis. Odds ratios }(95 \% \text { confidence interval): bronchitis } 1.45(1.32- \\
1.59) \text {; respiratory tract infections } 1.44(1.31-1.59) \text {; respiratory tract infections excluding } \\
\text { nonspecific upper respiratory tract infections } 1.50(1.32-1.70) \text {; respiratory tract infections in } \\
\text { children and neonates } 1.48(1.33-1.65) \text {. }\end{array}$ & 9 \\
\hline $\begin{array}{l}\text { Updated, comprehensive review of the } \\
\text { epidemiological evidence collected from } \\
\text { original studies and meta-analyses, } 2011\end{array}$ & $\begin{array}{l}\text { Review of publications in peer-reviewed journals by November 2009; Total for references } \\
\text { less than } 148 \text { because studies may have reported multiple findings. } \\
\text { Evident dampness or mould had consistent positive associations with multiple allergic and } \\
\text { respiratory effects. Epidemiologic studies and meta-analyses showed indoor dampness or } \\
\text { mould to be associated consistently with increased asthma development and exacerbation, } \\
\text { current and ever diagnosis of asthma, dyspnoea, wheeze, cough, respiratory infections, } \\
\text { bronchitis, allergic rhinitis, eczema, and upper respiratory tract symptoms. Associations } \\
\text { were found in allergic and nonallergic individuals. Evidence strongly suggested causation of } \\
\text { asthma exacerbation in children. }\end{array}$ & 10 \\
\hline $\begin{array}{l}\text { Systematic review and quantitative } \\
\text { meta-analysis, } 2012\end{array}$ & $\begin{array}{l}\text { Sixteen studies: } 11 \text { cohort and } 5 \text { incident case-control studies. The summary effect estimates } \\
\text { (EE) based on the highest and lowest estimates for the relation between any exposure and } \\
\text { onset of asthma were calculated. } \\
\text { The evidence indicates that residential dampness and moulds are determinants of developing } \\
\text { asthma. The association of the presence of visible mould and especially mould odour are } \\
\text { risk factors for asthma and points towards mould-related causal agents. }\end{array}$ & 11 \\
\hline $\begin{array}{l}\text { Review of the literature and quantitative } \\
\text { meta-analysis, } 2013\end{array}$ & $\begin{array}{l}\text { Thirty-one studies on rhinitis, allergic rhinitis, or rhinoconjunctivitis were included. } \\
\text { The largest risk was observed in relation to mould odor (rhinitis: } 2.18 \text { [95\% CI, } 1.76-2.71] \text {; } \\
\text { allergic rhinitis: } 1.87 \text { [ } 95 \% \text { CI, } 0.95-3.68] \text { ). The risk related to visible mould was also } \\
\text { consistently increased (rhinitis: } 1.82 \text { [95\% CI, } 1.56-2.12] \text {; AR: } 1.51 \text { [ } 95 \% \text { CI, } 1.39-1.64] \text {; } \\
\text { rhinoconjunctivitis: } 1.66 \text { [ } 95 \% \text { CI, } 1.27-2.18] \text { ). In addition, exposure to dampness was } \\
\text { related to increased risk of all types of rhinitis. Remediation of moisture and mold damage is }\end{array}$ & 12 \\
\hline
\end{tabular}




\begin{tabular}{|c|c|c|}
\hline Publication type and the publication year & Study design and main conclusions & Reference \\
\hline Mini review of the literature, 2014 & $\begin{array}{l}\text { likely to prevent chronic rhinitis. } \\
\text { The review summarizes the available data on the low-molecular-weight toxins reliably } \\
\text { known from fungi common on damp building materials, the toxins that have been measured } \\
\text { on mouldy building materials and the new understanding of the role that they play in the } \\
\text { documented health effects of individuals living and working in damp and mouldy buildings. }\end{array}$ & 13 \\
\hline $\begin{array}{l}\text { Summing-up the reviews and meta-analyses } \\
\text { since } 2004 \text { on microbial exposures and } \\
\text { allergic versus nonallergic mechanisms, } 2015\end{array}$ & $\begin{array}{l}\text { All reviewed studies on adults and children point to the fact that staying in a moisture-damaged } \\
\text { building puts an occupant at risk for upper and lower respiratory symptoms, such as the onset } \\
\text { and exacerbation of asthma, and increased rate of respiratory infections, hypersensitivity } \\
\text { pneumonia, allergic rhinitis, allergic rhinoconjunctivitis, eczema, and bronchitis. }\end{array}$ & 14 \\
\hline $\begin{array}{l}\text { Original paper estimating the costs of allergic } \\
\text { rhinitis, acute bronchitis and asthma are due } \\
\text { to moisture and mould damage, } 2016\end{array}$ & $\begin{array}{l}\text { The total annual cost to society attributable to dampness and mould is estimated to be } \$ 3.7 \\
\text { (2.3-4.7) billion for allergic rhinitis, } \$ 1.9(1.1-2.3) \text { billion for acute bronchitis, } \$ 15.1 \text { (9.4- } \\
20.6 \text { ) billion for asthma morbidity, and } \$ 1.7(0.4-4.5) \text { billion for asthma mortality. }\end{array}$ & 15 \\
\hline $\begin{array}{l}\text { Review of the literature to find metrics for } \\
\text { defining unhealthy levels of residential } \\
\text { dampness and mould } 2017\end{array}$ & $\begin{array}{l}\text { Visible mould, and odour indicative for hidden residential moisture and mould is associated } \\
\text { with a significantly increased risk of adverse respiratory health. }\end{array}$ & 16 \\
\hline $\begin{array}{l}\text { Review of the literature to search studies of } \\
\text { quantified building moisture and occupant } \\
\text { health effect } 2018\end{array}$ & $\begin{array}{l}3 \text { eligible studies. } \\
\text { Water damage of building materials is an underestimated problem. Moisture in the walls of a } \\
\text { building is linked to the development of asthma. Moisture damage is associated with } \\
\text { respiratory health problems and allergies, as well as severe and moderate atopic dermatitis. } \\
\text { Analyses were performed using data from adults and children combined, using only data } \\
\text { from children, and using data from adults and children after excluding two studies }\end{array}$ & 17 \\
\hline Meta-analysis, 2019 & $\begin{array}{l}\text { The odds ratios of } 1.32 \text { for cough and } 1.68 \text { for wheeze suggest moderate increases in health } \\
\text { risk. Studies not included in the meta - analyses provide additional evidence that dampness } \\
\text { and mould in schools are associated with adverse health outcomes. }\end{array}$ & 18 \\
\hline $\begin{array}{l}\text { Review of the the main methods for detection } \\
\text { and characterization of fungal aerosols and in } \\
\text { vitro research to study mould toxicity and } \\
\text { extrapolation on airway exposure } 2020\end{array}$ & $\begin{array}{l}\text { Hyphal fragments of prevalent mould species with strong pro - inflammatory potential may } \\
\text { be particularly relevant candidates for respiratory diseases associated with dampness and } \\
\text { mould - contaminated indoor air. }\end{array}$ & 8 \\
\hline
\end{tabular}

\section{Conclusions}

We suggest that recognition of DM-associated asthma and preceding respiratory problems due to DM exposure is important during the COVID-19 pandemic. Avoidance of moldy environment should be highly recommended.

\section{References}

[1] Tuuminen T, Lohi J. Immunological and toxicological effects of bad indoor air to cause Dampness and Mold Hypersensitivity Syndrome. Aims of Allergology. 2018, 2 (4): 190-204 doi: 10.3934/Allergy.2018.4.190

[2] Valtonen V. Clinical Diagnosis of the Dampness and Mold Hypersensitivity Syndrome: Review of the Literature and Suggested Diagnostic Criteria. Front Immunol. 2017 Aug 10; 8: 951. doi: 10.3389/fimmu.2017.00951. eCollection 2017.

[3] Hyvönen S, Syrjälä H. Asthma Case Cluster during Renovation of a Water-Damaged and Toxic Building. $\begin{array}{llll}\text { Microorganisms } & 2019, & 7 & \text { 64 }\end{array}$ https://doi.org/10.3390/microorganisms 7120642.

[4] Jaakkola MS, Lajunen TK, Jaakkola JJK. Indoor mold odor in the workplace increases the risk of Asthma-COPD Overlap Syndrome: a population-based incident case-control study. Clin Transl Allergy. 2020 Jan 15; 10: 3. doi: 10.1186/s13601019-0307-2. eCollection 2020.

[5] Hurra $\beta$ J, Heinzow B, Aurbach U, ym. Medical diagnostics for indoor mold exposure. Int J Hyg Environ Health 2017; 220: 305-328.
[6] Tuuminen T, Lohi J. Revising the criteria for occupational mould-related disease: arguments, misconceptions, and facts. EMJ Allergy Immunol. 2018; 3 (1): 128-35.

[7] Wolff H, Mussalo-Rauhamaa H, Raitio H ym. Patients referred to an indoor air health clinic: exposure to waterdamaged buildings causes an increase of lymphocytes in bronchoalveolar lavage and a decrease of CD19 leucocytes in peripheral blood. Scand J Clin Lab Invest. 2009; 69 (5): 53744. doi: 10.1080/00365510902770061.

[8] Holme JA, Øya E, Afanou AKJ, Øvrevik J, Wijnand E. Characterization and pro-inflammatory potential of indoor mold particles. Indoor Air. 2020 Feb 20. doi: 10.1111/ina.12656.

[9] Fisk WJ, Eliseeva EA, Mendell MJ. Association of residential dampness and mold with respiratory tract infections and bronchitis: a meta-analysis. Environ Health. 2010; 9: 72. doi: 10.1186/1476-069X-9-72.

[10] Mendell MJ, Mirer AG, Cheung K, Tong M, Douwes J. Respiratory and allergic health effects of dampness, mold, and dampness-related agents: a review of the epidemiologic evidence. Environ Health Perspect 2011; 119: 748-56.

[11] Quansah R, Jaakkola MS, Hugg TT, Heikkinen S, Jaakkola JK. Residential dampness and molds and the risk of developing asthma: a systematic review and meta-analysis. PLoS One. 2012; 7 (11): e47526. doi: 10.1371/journal.pone.0047526.

[12] Jaakkola MS, Quansah R, Hugg TT, Heikkinen S, Jaakkola JK. Association of indoor dampness and molds with rhinitis risk: a systematic review and meta-analysis. J Allergy Clin Immunol. 2013; 132: 1099-110.

[13] Miller JD, McMullin DR. Fungal secondary metabolites as harmful indoor air contaminants: 10 years on. Appl Microbiol Biotechnol. 2014; 98: 9953-66. 
[14] Cox-Ganser JM. Indoor dampness and mould health effectsongoing questions on microbial exposures and allergic versus nonallergic mechanisms. Clin Exp Allergy. 2015; 45: 1478-82.

[15] Mudarri DH. Valuing the Economic Costs of Allergic Rhinitis, Acute Bronchitis, and Asthma from Exposure to Indoor Dampness and Mold in the US. J Environ Public Health. 2016; 2016: 2386596. doi: 10.1155/2016/2386596.

[16] Mendell MJ, Kumagai K. Observation-based metrics for residential dampness and mold with dose-response relationships to health: A review. Indoor Air. 2017; 27: 50617.

[17] Mendell MJ, Macher JM, Kumagai K. Measured moisture in buildings and adverse health effects: A review. Indoor Air. 2018; 28: 488-99.

[18] Fisk WJ, Chan WR, Johnson AL. Does dampness and mold in schools affect health? Results of a meta-analysis. Indoor Air. 2019; 29: 895-902. 